\title{
Lo Profético como Estilo en la Brevísima Relación de la Destrucción de Indias, de Bartolomé de las Casas
}

\author{
¡O planto de Xeremías \\ vente agora a contexar \\ con el mio! (hacia 1534) \\ Garci Sánchez de Badajoz
}

Según la opinión de Ramón Menéndez Pidal el padre Las Casas sufrìa de una escisión de personalidad explicable en la paranoia: "Ni era ni santo ni era impostor, ni malévolo ni loco; era sencillamente un paranoico."1 El juicio es excesivo y pretende ilustrar desde la sicologia lo que debe considerarse más bien una actitud literaria. La doble personalidad de fray Bartolomé es la del escritor y no la del paranoico, porque en él hay algo más que un cronista iracundo. Menéndez Pidal no desdeña del todo el oficio de Las Casas y en ese mismo y controversial libro apunta una intuición iluminante: "Las Casas imita el estilo de Isaǐas." Supone que la Historia de Indias es producto de una respuesta a cierto llamado superior, mensaje que "queda grabado en boj para testimonio sempiterno de la justicia divina." Señala otros varios pasajes de la amplia obra lascasiana que permiten ver a su autor como en cumplimiento de órdenes divinas; pero refiriéndose a la Brevisima relación. . ., y en su empeño por desacreditarla, Menéndez pasa por alto la misma postura que habia advertido en la Historia: que el libro pretende un tono y hasta una organización de profecǐa.

Marcel Bataillon se ha preguntado: "Las Casas, ¿un profeta?" Su conclusión, originada en el comentario de una epistola lascasiana de 1549, analiza usos metafóricos "frutos de una revisión estilisstica 
calculada para expresar con más fuerza la crueldad de la situación. Y aquí, en esta vehemencia metafórica intencionada, veo algo que recuerda a los profetas de Israel." Más adelante anota que el autor intercala frases bíblicas en su discurso con el mismo fin: "Las Casas aplica a la tragedia presente, con la mayor naturalidad, las frases bíblicas."2

Fueron las Escrituras para el religioso, sobre todo, manantial de preceptos para fundamentar su doctrina de evangelización pacífica. Una de sus mayores obras, Del único modo de atraer a todos los pueblos a la verdadera religión, es muestra detallada del fino conocimiento que Las Casas tuvo de la Biblia. Como lectura que motiva sus acciones, recuérdese que una determinación capital de su vida fue inspirada por cierta lección reflexiva del capítulo 34 de Eclesiástico: cuando renuncia a sus bienes, porque "determinó en sǐ mismo, convencido de la misma verdad, ser injusto y tiránico todo cuanto cerca de los indios destas Indias se cometía." 3 En esos días de la Pascua de Pentescostés de 1514 el clérigo decide convertirse en defensor de los indios, rechazando sus privilegios de encomendero. 4 Desde entonces fray Bartolomé recurre a las Escrituras como a ningún otro texto para acendrar su cristianismo, para apoyar sus alegatos, para justificar sus acusaciones.

Además, en lo literario, son años en que los hombres de letras comienzan a encontrar en la Biblia una fuente de inspiración poética. La melancolía ingresa como rasgo lírico definido en la poesía castellana, expresada, varias veces, en temas e imágenes biblicas: "a estas alturas del siglo XVI, los poetas refinados cultivan un "dolorido sentir', que en varios casos encuentra modelos en la Biblia".5 Yacaso sea Las Casas un precursor al desarrollar una imagen inédita en la prosa castellana: la tierra sola, ya estéril. 6

Américo Castro, desde otra perspectiva, llega también a ver en Las Casas el signo de lo profético y lo llama "nuevo y desatentado profeta de un nuevo Israel, salvaba a los indígenas para que el reino de la palabra divina fuese instaurado."7

Las preferencias biblicas del historiador se justificarìan, además, en razones de linaje: "¿No habrá consagrado su vida a exigir para los nuevos cristianos de América un tratamiento y unos métodos de conversión que habiaan sido vedados a los cristianos nuevos de Sevilla? "8 La pregunta es más que apropiada si se piensa en los empeños evangelizantes del dominico; y no se guarda éste, en su dolido libro, una fuerte y condenatoria alusión al Santo Tribunal cuando narra crueldades cometidas por los "cristianos" en Venezuela: “Todas estas 
cosas están probadas con muchos testigos por el fiscal del Consejo de las Indias, e la pobranza está en el mesmo Consejo, e nunca quemaron vivos a ningunos destos tan nefandos tiranos." (p. 149) 9

El trato de Las Casas con las Escrituras resulta indiscutible en lo vital y en lo literario. En la Brevisima relación. ..., al parecer, tal contacto alcanza un tono especial: el discurso parece imitar el estilo, la organización y hasta algunas imágenes del libro de Jeremías.

Desde la situación primera, extra textual, Jeremías es modelo más que adecuado para las intenciones narrativas de un Las Casas que escribe como en misión divina, "procurando echar el infierno de las Indias, y que aquellas infinitas muchedumbres de ánimas redimidas por la sangre de Jesucristo no perezcan sin remedio..." (p. 195). El escrito del profeta, por su parte, obedece al mandato directo de Dios: "Recibió Jeremías palabra de Yavé diciéndole: toma un volumen y escribe en él todo cuanto yo te he dicho..." (36:1), y no es el único pasaje en Jeremias donde se ordena la palabra escrita para atestiguar acusaciones: "Llegó a Jeremías palabra de Yavé, diciendo: escribe en un libro todo cuanto yo he dicho, porque viene tiempo..." (30:1). Ambos versículos podrían encabezar casi toda la producción lascasiana, pero como se verá, alcanzan especial interés en el caso de la Brevisima relación. . .. Los mandatos divinos inspirarán en el historiador una segunda imagen, aun más efectiva, porque el escrito primero del profeta es desoído y roto por el destinatario real: "Estaba el rey en las habitaciones de invierno, era el noveno mes, y tenía delante de sí un brasero encendido; y según iba leyendo Judí tres o cuatro columnas del volumen, lo iba rasgando el rey con el cuchillo del escriba y lo arrojaba al fuego del brasero, hasta que lo quemó todo." (36:22-23) ¿Sintió Las Casas aludido su escrito en esos versículos? Quién sabe, pero en el prólogo dos líneas sugieren cierta negligencia del prìncipe porque en ellas le recuerda el cronista que hace algún tiempo hizo llegar a sus manos páginas que ahora vuelve a enviar "en molde", porque, "puede haber sido que, o Vuestra Alteza no las leyó o que ya olvidadas las tiene. . " La insistencia del narrador acaso encontró inspiración en el mandato repetido de Yavé a Jeremías: "Toma un nuevo volumen y escribe en él todos los sermones que habǐa en el primero, que quemó Joaquĭn, rey de Judá." (36:28) Con esa misma tenacidad fray Bartolomé escribe desde 1516 hasta poco antes de su muerte cartas, memoriales, "remedios" y peticiones a la 
Corona porque, como confiesa en su testamento, "la bondad y misericordia de Dios tuvo por bien elegirme su ministro..."10 En Las Casas como en el profeta se justifica la reiteración en el deseo de servir al rey, de contribuir al bienestar del estado. Yavé aconseja a Jeremías: ". . . a ver si oyendo la casa de Judá todos los males que yo pienso traer sobre ella, se convierta cada uno de sus malísimos caminos. .." (36:3). No lejos de esa intención declara Las Casas la suya: "Suplico a Vuestra Alteza lo reciba e lea con la clemencia e real benignidad que suele las obras de sus criados y servidores que puramente, por solo el bien público e prosperidad del estado real, servir desean..." (p. 13).

Y en la Brevisima relación. . . hasta se deja ver el matiz de imperecedera que anhela el cronista para su palabra, insistiendo en que su discurso es apenas cifra: "Y es verdad que si hobiese de decir, en particular, sus crueldades, hiciese un gran libro que al mundo espantase." (p. 93) ${ }^{11}$ Porque espanto y temor debe causar un testimonio capaz de doblegar la voluntad de un rey, de influir en sus pareceres, de imponerse sobre sus consejeros, en fin, debe lograr el efecto que produjo la lectura del dictado profético entre los cortesanos: "...cuando oyeron , pues, todo aquello, mostráronse unos a otros atónitos y dijeron a Baruc: tenemos que comunicar esto al rey." (36:15-16). Las Casas mismo ha ido a la corte "a informar al Emperador nuestro señor. . causando a los oyentes con la relación una manera de éxtasi y suspensión de ánimos..." (p. 5). Y como en el caso de Jeremías, sus denuncias le crean enemigos y es impugnado porque su prédica amenazó detener la conquista. Los grandes de Indias deben haberle semejado los palatinos bíblicos: "Y dijeron los grandes al rey: hay que matar a ese hombre porque con eso hace flanquear las manos de los guerreros que quedan en la ciudad y las de todo el pueblo, diciéndoles cosas tales. Ese hombre no busca el bien de este pueblo sino su mal." (38:4). Extrañamente, esos mismos argumentos habǐan servido a Rodrigo de Contreras, uno de los más enconados enemigos de Las Casas en Indias, para acusarle de que con su prédica había hecho "flanquear las manos de los guerreros". Siendo gobernador de León, en Nicaragua, Contreras "presentó un escrito de pedimento con ciertas probanzas en él insertas" contra el dominico, cuyas palabras habian sublevado a varios soldados en contra de una expedición de descubrimiento en la que iban intereses reales. 12

Pero no le quedó a Las Casas, como antes a Jeremías, más que contemplar el triunfo de la desobediencia a la voz divina, el desacato a un Señor que amenazaba venganza. Al presenciar esa irreverencia, 
Las Casas se atribuye el papel de historiador mensajero, nuncio del castigo que por faltar a las normas cristianas tendría que recibir España. No por otras razones concluyó algunos de sus escritos con advertencias apocalïpticas. Asï, terminando su Brevisima relación. . . señala que la obra es también producto de la "compasión que he de mi patria, que es Castilla, no la destruya Dios por tan grandes pecados contra su fe y honra cometidos. .." (p. 195). Acentuando en esta obra el tono profético, ha advertido antes: “. . .y el día del juicio será más claro, cuando Dios tomare venganza de tan horribles e abominables insultos como hacen en las Indias los que tienen nombre de cristianos." (p. 133). También en 1542, año de escritura de la Brevisima relación. .., habìa amenazado en su Octavo remedio: "El daño y jactura que a la Corona real de Castilla y León por esta causa ha venido y a toda España verná, despoblando y matando como por ella mesma se matará y despoblará todo el resto que dellas queda, los ciegos lo verán, los sordos lo oirán, los mudos lo clamarán y los muy prudentes lo juzgarán. . y que por aquellos pecados, por lo que leo en la Sagrada Escritura, Dios ha de castigar con horribles castigos e quizá totalmente destruirá toda España."13 Y diez años después, en 1552, cuando publica su polémico libro, y concluye la famosa disputa con Sepúlveda, escribe para sellar sus alegatos: "porque los reyes de Castilla no pierdan las Indias, e porque la total perdición de tantas gentes y despoblación de tan luengas tierras no haya efecto, como presto lo habrá, e para impedir los azotes que Dios da e más crueles que ha de dar por ellos a toda España. . ."14

Al tono acompañaba la acción porque cinco años antes había vuelto a la Corte, para no regresar ya más a Indias, situando un nuevo campo para sus empeños: "Voy a dirigirme a los grandes y les hablaré, éstos ya conocerán los caminos de Yavé, los mandatos de su Dios." (Jeremías 5:4-5). Son tiempos de incansable ajetreo para el dominico que alcanzaba entonces plena posesión de sus aptitudes literarias e ideológicas. Disimulará, pues, como buen polemista, las huellas formales del paradigma biblico que parece inspirarle, sin ahorrar nada de lo que allǐ sirve para sostener sus acusaciones que van también dirigidas contra un pueblo que, olvidando la palabra divina, seguía nuevos becerros de oro.

De las cuatro profecías mayores, el Libro de Jeremías parece más próximo al texto de Las Casas porque sus versïculos desarrollan con especial fuerza la imagen más efectiva de la prosa lascasiana: la 
de la soledad, la de las tierras baldías. En ambas obras descuella el lamento por la tierra que fue saqueada, abandonada.

Desde el párrafo introductorio de la Brevisima relación... acentúa el narrador la abundancia de gente que en aquellas regiones hubo antes de la llegada de los conquistadores: "...que todas estaban e las vimos las más pobladas e llenas de naturales gentes, indios dellas, que puede ser tierra poblada en el mundo... todas llenas como una colmena de gentes. .. que parece que puso Dios en aquellas tierras todo el golpe o la mayor cantidad de todo el linaje humano." (p. 15). No hay pasaje donde al alabar la calidad del suelo olvide el cronista la abundancia de gentes que lo habitaban. Así, por ejemplo, escribe de las tierras de Nueva España: "estas tierras todas eran las más pobladas e llenas de gentes que Toledo e Sevilla, y Valladolid y Zaragoza juntamente con Barcelona...."(p. 65); de la provincia de Jalisco cuenta: “. . estaba entera e llena como una colmena de gente poblatísima e felicísima..." (p. 97); dice, finalmente, que los españoles encontraron en el reino de Nueva Granada "unas felicísimas e admirables provincias llenas de infinitas gentes mansuetïsimas y buenas como las otras. .." (p. 175)15. Esta visión primera, de plenitud divina, contrasta violentamente con la que domina los párrafos siguientes: el abandono, la muerte. Lo que antes fue colmena feliz es ahora desolación y silencio: "La isla de Cuba... está hoy cuasi toda despoblada. La isla de Sant Juan e la de Jamaica, islas muy grandes e muy felices e graciosas, están ambas asoladas. Las islas de los Lucayos. . . no hay hoy una sola criatura." (p. 19). Tal procedimiento de oponer un pasado esplendoroso a un presente de soledad y dolor será rigurosamente mantenido por el historiador, develando en ese uso su clara voluntad narrativa, su preciso deseo de hacer resaltar contrastes, al modo bíblico. Las heredades de Dios, hasta hacía poco repletas de gente son ahora el vergel saqueado: “...han convertido mis deleitosos campos en desolado desierto. Hicieron de ella campo de desolación y está ante mí triste y asolada. Toda la tierra es desolación por no haber quien recapacite en su corazón" (Jeremías 12: 10-11). Casi como imitando el lamento del profeta el narrador de la Brevisima relación. . ., quejoso e impotente, va cerrando sus capitulos con la imagen de la tierra sola: "Por manera que no hay hoy vestigio ni señal de que haya habido allí pueblo ni hombre nacido, teniendo treinta leguas llenas de gente de señorǐo. ..", dice de la Tierra Firme (p. 57); de Jalisco cuenta que ". . agora de nuevo han hecho en ellos tan grandes crueldades que cuasi han acabado de despoblar e asolar toda aquella gran tierra, 
matando infinitas gentes" (p. 101); de Venezuela escribe que unos conquistadores que han ido allá hace poco "hallaron toda la tierra, más de doscientas leguas, tan quemada y despoblada y desierta, siendo poblatísima e felicǐsima como es dicho, que ellos mesmos, aunque tiranos e crueles, se admiraron y espantaron de ver..." (p. 149). 16 Lo que en Jeremías es visión anticipada del dolor ("Miré a la tierra y todo era vacio y confusión. . Miré y no se veía un hombre y las aves del cielo habían huido todas." 4:23-24) en Las Casas es testimonio de un presente de tristezas, de algo ciertamente acaecido ("He visto por mis mismos ojos que en muy breves días las han destruido y del todo despoblado..."). Ambos atestiguan el arrasamiento y ambos se quejan con lamento semejante porque la causa del llanto del profeta viene a ser la misma del suyo: "Llorad y gemid sobre los montes, lamentaos por los pastizales del desierto, porque están desolados, no hay quien pase por ellos, ni se oye el balar de los rebaños. Desde las aves del cielo hasta las bestias de la tierra, todos huyeron, todos se fueron." (9:10-11). El historiador pareciera recoger esta imagen y haciéndose actor de ella pasa por esos campos desolados que en su experiencia no son otros que los de Naco y Honduras: “. . aquellas provincias e reino de Naco y Honduras, que verdaderamente parescían un paraǐso de deleites y estaban más pobladas que la más frecuentada y poblada tierra que puede ser en el mundo; y agora pasamos e venimos por ellas y las vimos tan despobladas y destruidas que cualquiera persona, por dura que fuera, se le abrieran las entrañas de dolor." (p. 83). 17

A la espada y al hambre, sobre todo, se debe la despoblación de Indias; la primera es en la prosa lascasiana el simbolo que distingue la crueldad de los invasores (“. . .dicen: '¡Santiago y a ellos!' e comienzan con las espadas desnudas a abrir aquellos cuerpos desnudos..." p. 73). El castigo sufrido por los americanos aparecía también escrito en otro versículo de Jeremialas: "Los fuertes morirán al filo de la espada; sus hijos y sus hijas morirán de hambre." (11:22). La palabra profética se va cumpliendo en Indias y el tono fatalista que a ratos muestra la relación de fray Bartolomé resulta, pues, explicable al confrontar imágenes, como esta de la ineluctable espada: "Y a pueblo muy grande e poderoso vinieron (que estaban descuidados más que otros e seguros con su innocencia) y entraron los españoles y en obra de dos horas casi lo asolaron, metiendo a espada los niños e mujeres e viejos con cuantos matar pudieron que huyendo no se escaparon." (p. 85). La tan pesimista imposibilidad de la huida estaba también anunciada -al menos para la inspiración del historiador- en 
Jeremǐas: "No salgáis al campo, no andéis por los caminos; por todas partes nos sale al encuentro la espada del enemigo y el espanto." (6:25).

En la tierra de abundancia que era el Nuevo Mundo descrito por Las Casas el hambre resulta un castigo tan desproporcionado como la espada. Llega a decir el dominico que en cierta ocasión "los cristianos tomaron a los indios cuanto maïz tenían. .. por lo cual murieron de hambre más de veinte o treinta mil ánimas e acaesció mujer matar su hijo para comello de hambre." (p. 61). Hasta el hecho de canibalismo, más proclamado que documentado en América, trae el recuerdo de otro pasaje de Jeremias, algo semejante: "Les haré comer la carne de sus hijos y de sus hijas, y se comerán unos a otros en las angustias del asedio y del hambre a que los reducirán sus enemigos, los que de muerte los persiguen." (19:9). Asi", pues, esas "naturales gentes", que vivian allí por voluntad de Dios que les dio la tierra ("criadas a la imagen de Dios y redimidas por su sangre") han sido avasalladas, vejadas y abandonadas luego, al modo bíblico: "no serán llorados no serán recogidos, no serán sepultados, quedarán como estiércol sobre el haz de la tierra." (25:33); asî se lamenta Las Casas en su prosa: "porque plugiera a Dios que como bestias las hubieran tractado y estimado, pero como y menos que estiércol de las plazas." (p. 23)

Es difícil dudar que las profecías no hubieran proporcionado una de las imágenes centrales al desarrollo de esta comparación: la del pueblo americano visto como el antiguo pueblo de Israel. Mayor razón de dolor para el cronista porque el castigo era a toda luces inmerecido: la ira de Dios se ha descargado contra quienes ni siquiera han oỉdo antes su palabra. El historiador invierte conscientemente la imagen tradicional insistiendo en la crueldad hispánica y en la inocencia del americano para hacer así resaltar el carácter inaudito e idolátrico de la conquista, ". . . cosa tan injusta e crueldad tan nunca vista, en tantos innocentes sin culpa perpetrada..." (p. 73). Conmovedora coincidencia descubría Las Casas en el destino de los pueblos de Israel y de América: el primero ol̈a del profeta su trágico porvenir; el otro asistía en la crónica a su vivida desvastación. Cuán lamentable proceso para el dominico, que bien sabía de la bondad y limpieza de las gentes del Nuevo Mundo: "aptísimos para recebir nuestra sancta fe católica... e las que menos impedimentos tienen para esto que Dios crió en el mundo... estas gentes eran las más bienaventuradas del mundo si solamente conocieran a Dios." (p. 17). No hay desobediencia en el hombre de América y, sin embargo, debe sufrir un castigo que en mucho se parecía al anunciado contra el pueblo rebelde de Israel. 
La comparación entre el hombre del Nuevo Mundo y el bíblico no era, en todo caso, una novedad: ya en uno de los primeros libros sobre América - Suma de Geografía, Sevilla, 1519- Martín Fernández de Enciso establecía la relación; pero el paralelo entonces había servido para justificar las expediciones de conquista. Pareciera, así, que el asunto tiene doble propósito en fray Bartolomé: utiliza el poderoso modelo que le facilitaba el Antiguo Testamento para clausurar la relación entre los dos pueblos, porque uno había vivido en pecado $y$ el otro en virtuosa inocencia natural; y, sellando las diferencias, describe entre los españoles todos los defectos que Jeremías denunciaba entre los judíos. Por eso, en su opinión, la motivación de los españoles es una sola: el oro: "La causa porque han muerto y destruido ha sido solamente por tener por su fin último el oro y henchirse de riquezas en muy breves días e subir a estados muy altos e sin proporción de sus personas..." (p. 21). Nuevos vellocinos de oro aparecian para los castellanos y no para los pretendidos descendientes de Israel.18 La codicia lleva a los castellanos, todos, a olvidarse de los principios divinos: "lo mesmo hacían los oficiales del rey, enviando cada uno los más mozos o criados que podía, y el obispo primero de aquel reino enviaba también sus criados, por tener parte en aquella granjería. Más oro robaron en aquel tiempo..." (p. 53). Ningún compromiso guardaban los españoles, ni con leyes divinas ni humanas; habỉan también faltado a su convenio. ${ }^{19}$ Por todo el libro se documenta la ausencia de prácticas cristianas y Las Casas deja lugar a su ironía en giros como "... los que allá han pasado, que se llaman cristianos. .." (p. 30); “.. .infinitas e inauditas crueldades que hicieron los que se llaman cristianos..." (p. 107), como resonancia de aquel breve y penetrante versículo de Jeremías: "Te tienen a ti en la boca, pero está muy lejos de ti su corazón." (12:2).

Las Casas va delineando en su obra uno de los grandes temas de la época: la necesidad de hacer entender a los cristianos que el cristianismo era una práctica, no una simple denominación. Reniegan los españoles de su credo, y la empresa que acometen es ante los ojos del historiador de ignominiosa tradición: ". . .e júzguese si fue menor pecado éste que el de Jeroboan: qui peccare fecit Israel, haciendo los dos becerros de oro para que el pueblo los adorase, o si fue igual al de Judas, o que más escándalo causase. Estas, pues, son las obras que los españoles que van a las Indias, que verdaderamente muchas e infinitas veces, por la cudicia que tienen de oro, han vendido y venden hoy en este dîa e niegan y reniegan a Jesucristo." (p. 113). Bastante se 
aproxima la prosa lascasiana a la de los erasmistas españoles, pero publicando en Sevilla iy en 1552! no es difícil conjeturar por qué el autor elude caulquiera identificación explícita con la doctrina erasmista. 20

Los españoles se convierten en Indias en deshonra de Dios, despreciando su doctrina han seguido a los falsos dioses como antes el pueblo judío; desarrollando ese paralelo Las Casas alcanza una de las imágenes más poderosas de su escrito: aquella en que los naturales americanos se muestran convencidos de que el Dios de los conquistadores es el oro: “. . .'tienen un dios a quien ellos adoran e quieren mucho, y por habello de nosotros para lo adorar, nos trabajan de sojuzgar e nos matan.' Tenía cabe sí una cestilla llena de oro en joyas e dijo: 'Veis aquii el dios de' los cristianos; hagámosle si os parece areitos (que son bailes y danzas) e quizá le agradaremos y les mandará que no nos hagan mal.' " (p. 43). En la ingenuidad del cacique que pronuncia ese consejo se oculta la sutileza lascasiana que forja su discurso en la doble vertiente de la ironía y la alusión, aunque alguna vez pierda el tono sutil y formule su acusación en lengua bien directa: "Comenzó a hacer las crueldades maldades que solía, e que todos allá tienen de costumbre, e muchas más, por conseguir el fin que tienen por dios, que es el oro." (p. 99).

Si la ideología del libro es transparente en su adhesión por la palabra original del Evangelio, en la síntesis de su construcción se advierte, igualmente, el reflejo inverso de la fuente bíblica porque la palabra de Jeremías detallaba el rigor que sufrían los inocentes americanos: "Contra vosotros, casa de Israel, voy a traer yo de lejos un pueblo, palabra de Yavé; un pueblo fuerte, un pueblo de antiguo abolengo, un pueblo de lengua extraña, cuyas palabras no entenderéis. Su aljaba es como sepulcro abierto, todos ellos valerosos; y devorarán tus cosechas y tu pan, a tus hijos y a tus hijas. Devorará tus rebaños y tus vacadas, tus viñas y tus higueras, $y$ asolarìa tus ciudades..." (5:15-17).

Consecuente con el tono bíblico de su relación Las Casas se refiere reiteradamente al hombre del Nuevo Mundo con el inequívoco "ovejas". La comparación queda establecida en las primeras páginas del libro: "En estas ovejas mansas, y de las calidades susodichas por su Hacedor y Criador asi dotadas, entraron los españoles desde luego que las conocieron como lobos e tigres y leones cruelísimos de muchos días hambrientos." (p. 19). El pasaje cifra la fuerza expresiva y simbólica que pretende y alcanza la pluma del dominico porque invierte la orden de Jesús (Mateo 10:16) cuando da instrucciones a 
sus apóstoles: "Os envio como ovejas en medio de lobos; sed prudentes como serpientes y sencillos como palomas." Más adelante cita Las Casas otro versículo de Mateo (Iuntes docete omnes gentes, 28:19) condenando la ausencia de prédica cristiana entre los naturales y defendiendo su derecho a la enseñanza evangélica. ${ }^{21}$ Olvidados de Dios y en deservicio de su rey (". . . han perdido todo temor a Dios y al rey e se han olvidado de sí mesmos...", p. 65) los españoles eran fáciles de comparar con los malos pastores que en vez de cuidar el rebaño lo conducen al matadero: “ ¡Ay de los pastores que apacientan a mi pueblo: Vosotros habéis dispersado mi grey, la habéis descarriado y no habéis cuidado de ella..." (23:1-2). Las Casas alude a la misma imagen, pero de acuerdo a Zacarías (11:4-5), a quien cita, introduciendo el pasaje bỉblico más amplio del texto. De este modo va remarcando el narrador los rasgos positivos del hombre americano, portador de cierta virtud natural semejante a la de los primeros cristianos. De entrada dice de ellos: "son también gentes paupérrimas y que menos poseen ni quieren poseer de bienes temporales; e por esto no soberbias, no ambiciosas, no cubdiciosas. Su comida es tal que la de los sanctos padres en el desierto no parece haber sido más estrecha ni menos deleitosa ni pobre." (p. 17). La comparación, nada casual, confirma todo un sistema de alusiones que obligan a reconocer en los indios las virtudes de los primeros cristianos. Acaso coincidencia de una situación real con la bíblica, o tal vez acomodo de ciertos hechos por mano del cronista, dirá que también ejercitan la eucaristia como los santos padres donando de su comida "gran cantidad de pescado y pan..." (p. 45). En otra ocasión compara a los aborígenes con quienes representan una excelencia del cristianismo: "no dieron más causa los indios ni tuvieron más culpa que podrían dar o tener un convento de buenos e concertados religiosos para roballos e matallos y, los que da la muerte quedasen vivos, ponerlos en perpetuo captiverio e servidumbre de esclavos." (p. 37). 22 Todas las acusaciones contra la conquista expresadas por Las Casas no pueden menos que transformarse en críticas contra el estado del cristianismo en España. Y el suyo no es un caso aislado: Alfonso de Valdés, por ejemplo - el gran erasmista peninsular - no ve con buenos ojos lo que estaba sucediendo en otros reinos úl timamente conquistados. 23

Por ello que al discutir la calidad moral de sus compatriotas Las Casas ataca la empresa misma en que estaban empeñados y en la Brevisima relación. . . enfila su pluma contra uno de los temas recurrentes en la naciente historiografía indiana: el que describía la con- 
quista como una empresa de tinte heroico, legendario y hasta providencial. Por eso Las Casas se ocupa en invertir el símbolo oficial de la empresa española: misión de Dios, conducida bajo su apoyo, milagrosa por deferencia divina (". . piensan y dicen y escriben que las victorias que han de los inocentes indios asolándolos todas se las da Dios. ..", p. 101). 24 Pero en la Brevisima relación. . . la presencia de Dios se manifiesta invariablemente como castigo contra los españoles; en la prosa lascasiana sus poderes se transforman en azote contra el pueblo que le ha desobedecido: ". . quiso Dios mostrar ser aquella con las otras grande iniquidad e injusticia y envió aquella noche una tormenta que hundió todos los navios y ahogó todos los cristianos que en ellos estaban..." (p. 33); el tono de lo que en Jeremias es amenaza profética, en fray Bartolomé es narración y matanzas e tórnanse a Guatimala, donde edificaron una ciudad que agora con justo juicio, con tres diluvios juntamente, uno de agua e otro de tierra e otro de piedras más gruesas que diez y veinte bueyes, destruyó la justicia divinal." (p. 90).25 Acaso versículos de Jeremías inspiraron en el historiador la imagen de Dios en posesión de una naturaleza cuyos elementos domina: "A su voz se congregan las aguas del cielo. El hace subir las nubes desde los confines de la tierra; hace brillar el rayo entre la lluvia y saca los vientos de sus escondrijos." (51:16-6). Así desmiente Las Casas que el poder de Dios favorezca solo a los castellanos; Dios se revela siempre justiciero y, como tan claro lo da a entender el cronista, las malas obras levantaron su ira, asǐ sean las de los castellanos: de tal modo se ha manifestado por boca de Jeremías: "Haced siempre justicia, librad al oprimido de las manos del opresor, no sea que brote como fuego mi ira, y se encien$\mathrm{da}, \mathrm{y}$ arda sin que haya quien la apague, por la maldad de vuestras obras." (21:12). El argumento de Dios con España resulta inaceptable para un Las Casas que concibe el cristianismo verdadero más allá de lo nacional, que se ve en misión apostólica.

El versículo recién citado $(21: 12)$ no le fue desconocido; ése y otro de igual tono (22:3) cita como pruebas contra la esclavitud en un escrito suyo de 1547, impreso también en 1552.26 Tanto como el profeta se lamenta Las Casas por los horrores de la esclavitud y, como él, sufre por la víctima y por la ruptura de la familia, por la partida sin regreso: ". . .cuando salian iban llorando e sospirando los indios y diciendo: 'aquellos son los caminos por donde ibamos a servir a los cristianos, y aunque trabajásemos mucho, en fin, volvíamos a cabo de algún tiempo a nuestras casas e a nuestras mujeres y hijos; pero agora vamos sin esperanza de nunca jamás volver ni verlos 
ni de tener más vida" (p. 59), la situación de pesar concentrada en la palabra de ese sufriente y anónimo natural semeja un eco triste de cierta advertencia del profeta: "No lloréis por el muerto ni os lamentéis por él. Llorad y gemid por el que se va, porque no volverá más y no verá más la tierra en que nació" $(22: 10)$.

$\mathrm{El}$ asunto todo de la esclavitud bien pudiera inspirarse en capitulos de Jeremías que denuncian el quebrantamiento de la ley de servidumbre por parte de los israelitas, que llegado el tiempo prometido no han dado libertad a sus servidores, porque el pueblo español también habia faltado en el cumplimiento de los pactos establecidos para tratar a los indios. En la voz de Yavé: "Al llegar el año séptimo, cada uno dará libertad al hermano hebreo que se le haya vendido; te servirá durante seis años, pero luego le liberarás; más vuestros padres no me obedecieron, no me dieron oìdos." (34:14). Es por la misma falta que se queja Las Casas de sus compatriotas ante el rey: ". . .e la ceguedad de los que regian las Indias no alcanzaba ni entendía aquello que en sus leyes está expreso..." (p. 77). Se refiere a las leyes de Burgos (1512-13) que establecían el descanso y el tratamiento de semejante para los hombres del Nuevo Mundo. ${ }^{7}$ Es desde esa perspectiva, también, que se comprende mejor aquella insistencia en referirse a los americanos como "ánimas que Dios redimió con su sangre", "aquellos por quien Jesuchristo murió", "gentes criadas a la imagen de Dios e redimidas por su sangre". En tales expresiones confirma uno de los propósitos fundamentales de toda su gran obra: la igualdad de la naturaleza humana -cuando no la superioridad de la americana.

De ese modo va fray Bartolomé de Las Casas completando todo un sistema de alusiones que encuentra correlato en fuente biblica y, pretendiendo él mismo una estatura profética se transforma, además, en testigo de la apocalipsis que denuncia; su palabra, que predice y acusa, expresa la duda central del historiador y de Jeremías: “¿Hubo jamás pueblo alguno que cambiase de Dios, con no ser dioses esos? Pues mi pueblo ha cambiado su gloria por lo que de nada vale." (2:11); y más adelante, perdida la fuerza de la amenaza, agotados los recursos de la persuasión en pro de la conquista pacífica, de las leyes, de la justicia, su discurso sintetiza el desnudo lamento del Profeta: "Una cosa horrenda y abominable ha acontecido en esta tierra." $(5: 30)$. 


\section{NOTAS}

1. Ramón Menéndez Pidal. El padre Las Casas. Su doble personalidad. (Madrid: Espasa-Calpe, 1963). Juan B. Avalle Arce, acepta la dualidad compleja que delimita el cosmos ético del historiador: "El moralista -y Las Casas lo es, decididamente, en todas sus obras- se enfrenta y vive la angustia de una dualidad de absolutos opuestos: el bien y el mal." Por ello dice que la Brevísima relación. . "substancializa la visión apocalïptica" desde una posición donde no hay intermedios. Cf. "Las hipérboles del padre Las Casas", Revista de la Facultad de Humanidades (San Luis Potosì, México) 2 (1960), 33-55.

2. "Las Casas, ¿un profeta?", Revista de Occidente, 47 (1974) 279-291. El mismo Bataillon en artǐculo anterior escribió: "Pero Las Casas, aunque no es ningún santo inaccesible a la ambición, se siente un predestinado y considera la historia en que actúa como regida por la Providencia, y por consiguiente, como objeto de Profecia. Vaticinó ya en 1542, que tal vez la destrucción de las Indias por los españoles fuese castigada un dỉa con la destrucción de España. . . a Las Casas y a Ladrada, hospedados en San Gregorio de Valladolid, hacia 1552, los 1lamaban Elías y Enoch." "Estas Indias. . hipótesis lascasianas", Cultura Universitaria (Caracas) No. 66-7 (1959) 97-104.

3. Historia de las Indias. Edición de Agustîn Millares Carlo. Estudio preliminar de Lewis Hanke. (México: Fondo de Cultura Económica, 1951) III, p. 92.

4. Para un detallado análisis de las "conversiones" lascasianas, véase: Marcel Bataillon, "Le Clerigo Casas. Ci-devant Colon, reformateur de la colonisation", Etudes sur Bartolomé de Las Casas. (Paris: Centre de Recherches de L'Institut D'Etudes Hispaniques, 1965) pp. 1-94. Analiza allí el autor el giro inesperado que van alcanzando las conversiones de fray Bartolomé que, comenzando en la planificación agrícola, llega a la teorización sobre los derechos del natural americano.

5. Marcel Bataillon, “¿Melancolǐa renacentista o melancolǐa judǐa?”, Estudios hispánicos: homenaje a Archer M. Huntington. (Wellesley: Wellesley College, 1952) pp. 32-50. Bataillon comenta allì algunos poemas de Antonio de Villegas -que publica su Inventario en 1565, aunque autorizado en 1551- apuntando el uso de fuentes biblicas no solo en Villegas y en Garci Sánchez de Badajoz, sino que también en Camoens, Montemayor, Diego de San Pedro y otros. En la Brevísima relación. . L Las Casas es más bien prudente en sus citas bíblicas y se refieren éstas a versículos conocidos; en el año de aparición de su libro, 1552, el Santo Oficio procedĩa en Sevilla, ciudad donde se publicó el opúsculo, a nuevas censuras biblicas: J. Ignacio Tellechea Idígoras, "Biblias publicadas fuera de España secuestradas por la Inquisición de Sevilla en 1552", Bulletin Hispanique, 64 (1962) pp. 236-247.

6. No señala Karl Vossler en su obra La soledad en la poesía española (Madrid: Revista de Occidente, 1941) narraciones anteriores a 1542 en que haya asomos de tratamiento del tema.

7. De la edad conflictiva (Madrid: Taurus, 1961) p. 247. 
8. Claudio Guillén, "Un padrón de conversos sevillanos (1510)", Bulletin Hispanique, 65 (1963) pp. 49-98. En este documento aparecen los Casas entre las familias judǐas perseguidas. Por su parte, Américo Castro advierte en el encono y en el estilo lascasiano un rasgo de "casta" típico: "Aparte de los hechos antes aducidos [otros documentos que señalan a los Casas entre los conversos] que prueban que Las Casas era de casta de conversos, la forma de expresar ostentosamente la presencia y la importancia de su persona, lo confirma y lo remacha." "Fray Bartolomé de las Casas o Casaus", Cervantes y los casticismos españoles (Madrid: Alianza, 1974) pp. 190-227. A nuestro parecer, sobre todo tratándose de la Brevísima relación. .., el engrandecimiento personal del hablante parece antes que respuesta a un tono de linaje, intención por semejar una voz profética, por aproximarse a su paralelo bỉblico.

9. Todas las citas de la Brevisima relación de la destruición de las Indias, colegida por el obispo don fray Bartolomé de Las Casas o Casaus, de la Orden de Sancto Domingo, proceden del tomo I de la siguiente edición: Tratados de fray Bartolomé de Las Casas, prólogos de Lewis Hanke y Manuel Giménez Fernández. Transcripción de Juan Pérez de Tudela Bueso. Traducciones de Agustĭn Millares Carlo y Rafael Moreno. Edición facsimilar y transcrita. (México: Fondo de Cultura Económica, 1965).

10. La frase proviene de una "Cláusula del testamento" de fray Bartolomé. Obras escogidas de fray Bartolomé de Las Casas, BAE XC, Edición de Juan Pérez de Tudela Bueso (Madrid: Biblioteca de Autores Españoles, 1958) p. 539.

11. La frase muestra también cierto deseo de sintesis en el autor, que frecuentemente afirma: “. . son tantas las particularidades que en estas matanzas $e$ perdiciones de aquellas gentes ha habido, que en mucha escriptura no podrian caber (porque en verdad que creo que por mucho que dijese no pueda explicar de mil partes una)..." p. 37; juicios parecidos en pp. 67 y 192-3.

12. Asĩ dice el item sexto del informe presentado en 1536 por Contreras en contra del predicador: ". . .questando el dicho gobernador Rodrigo de Contreras enviando la dicha gente, que enviaba al dicho descubrimiento, en nombre de S. M. y estando allï el dicho Bartolomé de Las Casas, el dicho fray Bartolomé dijo e publicó, asĩ en el púlpito como fuera dél, que los que iban en el dicho descubrimiento iban en desservicio de Dios Nuestro Señor, y en gran cargo de sus conciencias, porque no iban por la vía que debian ir, lo cual redundaba y redundó escándalo entre la gente, e muchos se amotinaban para no querer ir allï, e dijo otras muchas cosas...", Colección de documentos inéditos del Archivo de Indias, sacados por Luis Torres de Mendoza (Madrid: Frĭas y Compañàa, 1867) VII, pp. 116-127.

13. Obras escogidas, p. 119.

14. ibid., p. 348. Sustanciando su convicción, hasta en el testamento insistió Las Casas acerca del castigo que caeria sobre España por sus faltas contra los hombres del Nuevo Mundo: “. . .e creo que por estas impias y celerosas e ignominiosas obras, tan injusta, tiránica y barbáricamente hechos en ellas y contra ellas, Dios ha de derramar sobre España su furor e ira, porque toda ella ha comunicado 
y participado poco que mucho en las sangrientas riquezas robadas y tan usurpadas y mal habidas y con tantos estragos e acabamiento de aquellas gentes, si gran penitencia no hiciere, y temo que tarde o nunca la hará. .." ibid., p. 540.

15. Pasajes similares se leen, sobre la Española, en p. 29; sobre Cuba, en p. 43; sobre las islas de Sant Juan y Jamaica, "una huertas y unas colmenas", en p. 41; sobre la Tierra Firme, en p. 49; sobre Guatemala, en p. 91; sobre Jalisco, en p. 103; sobre la costa de Paria, en p. 135; sobre Venezuela, en p. 143; sobre La Florida, en p. 155. Testigos le cuentan del Perú lo mismo: pp. 167-169.

16. Párrafos semejantes, sobre otros lugares del Nuevo Mundo, se leen en pp. 63, 67, 105, 135, 157 y 187.

17. Acerca de pueblos que han huido dejando abandonada su residencia milenaria insiste Las Casas en pp. 27, 47, 121, 143 y 145.

18. "¿Fueron los indios descendientes de las diez perdidas tribus de Israel?", titula Lewis Hanke un apéndice bibliográfico al respecto. El tema, como se sabe, fue tocado por varios cronistas de Indias. Cfr. Estudios sobre fray Bartolomé de Las Casas y sobre la lucha por la justicia en la conquista española de América (Caracas: Universidad Central de Venezuela, 1968) pp. 49-55. Sobre esta materia y también tocando el asunto de la secuela lascasiana, véase: Marcel Bataillon, "La herejía de fray Francisco de la Cruz y la reacción anti-lascasiana", Miscelanea de estudios dedicados a Fernando Ortiz I (La Habana, 1955) pp. 135-146.

19. Se burla Las Casas de los Requerimientos que debĭan leer los españoles al entrar en contacto con los indios: "Ibanse de noche los tristes españoles salteadores hasta media legua del pueblo, e allï aquella noche entre sĩ mesmos apregonaban o leian el dicho requerimiento, diciendo: 'Caciques e indios desta Tierra Firme de tal pueblo, hacemos os saber que hay un Dios e un Papa y un rey de Castilla que es señor destas tierras; venid luego a le dar la obediencia, etc. Y si no, sabed que os haremos guerra, e mataremos, e captivaremos, etc.' $\mathrm{Y}$ al cuarto del alba, estando los inocentes durmiendo con sus mujeres e hijos, daban en el pueblo, poniendo fuego a las casas, que comunmente eran de paja, e quemaban vivos los niños e mujeres y muchos de los demás..." (p. 51-3). Sobre los Requerimientos y su invalidez práctica, véase: Lewis Hanke, The Spanish Struggle for Justice in the Conquest of America (Boston: Little, Brown, 1965) 7a. ed. pp. 31-36.

20. Acerca del entusiasmo que por Erasmo se viviầ en esos años en Sevilla véase: "Sevilla a mediados del siglo xvi", en el prólogo que Manuel Giménez Fernández escribió para la edición de Tratados, antes citada, pp. LI-LVII. Es sobre todo en Bataillon donde se autoriza a pensar que Las Casas debía extremar su cautela, como hacen otros autores: "Ya hemos visto como un Zumárraga se sirve de los libros de Erasmo sin nombrarlo. Un Constantino se inspira en ellos sin nombrarlo tampoco. Volveremos a encontrar un erasmismo latente en el meollo mismo de la literatura espiritual cuyo impetu es tan poderoso en la España de entonces." (p. 548). Consúltense, además, pp. 509-547. Marcel Bataillon, Erasmo y España. Estudios sobre la historia espiritual del siglo xvi, trad. de Antonio Alatorre (México-Buenos Aires: Fondo de Cultura Económica, 
1966) 2a. ed. Años después servirá Las Casas como testigo en un juicio que por erasmista se siguió contra su amigo Bartolomé de Carranza. Cfr. J. Ignacio Tellechea Idìgoras, "Las Casas y Carranza: fe y utopia", Revista de Occidente 47 (1974) 403-427.

21. Al menos en tres ocasiones los castellanos, malos pastores, "insignes carniceros", son descritos como bestias al ataque de corderos: "Entraron en ellas, más pienso, sin comparación, cruelmente que ninguno de los otros tiranos que hemos dicho, e más irracional e furiosamente que crudelísimos tigres y que rabiosos lobos y leones." (p. 141); Más adelante: "Dan los tigres y leones en las ovejas mansas y desbarrigan y meten a espada tantos, que se pararon a descansar. .." (p. 183).

22. Comparaciones como la recién citada son frecuentes en la narración; veánse, por ejemplo, pp. 69, 103 y 133.

23. En su Diálogo de Mercurio y Carón, de hacia 1530, Valdés pone en boca del personaje Mercurio las siguientes palabras: "Fuime a un reino nuevamente por los christianos conquistado, y diéronme dellos mil quexas los nuevamente convertidos, diziendo que dellos havian aprendido a hurtar, a robar, a pleitear y a trampear. Hove compassión de los unos y de los otros, y harto de ver tanta ceguedad, tanta maldad y tantas abominaciones, no quise más morar entre tal gente, y maravillándome de los incomprehensibles juizios de Dios, que tales cosas sufre, me torné a exercitar mi oficio." Citamos según la edición de José F. Montesinos (Madrid: Espasa-Calpe, 1965) p. 19. Según Marcel Bataillon, que comenta ese pasaje, Mercurio se refiere a Granada. Cfr. Erasmo y España, p. 392.

24. Entre los escritos primeros y más populares que sin duda ayudaron a expandir esta creencia deben considerarse las cartas de Hernán Cortés. En su segunda relación (30 de octubre de 1520) escribe: "Bien paresció que Dios fue el que por nosotros peleó, pues entre tanta multitud de gentre y tan animosa y diestra en el pelear, y con tantos generos de armas para nos ofender, salimos tan libres." Cartas de Relación, Edición y prólogo de Manuel Alcalá (México: Porrua, 1971) p. 37. El párrafo no es aislado.

25. Pasajes muy semejantes a los recién citados se vuelven a encontrar en las pp. 31 y 177 .

26. Se trata del "Corolario primero", cuyas palabras iniciales leen: "Su Majestad es obligado de precepto divino a mandar poner en libertad todos los indios que los españoles tienen por esclavos." Cfr. Tratados, I, p. 595.

27. La ley XIII mandaba: “. . q' cojan oro con los yndios q' las tales personas touieren encomendados cinco meses del año, e q' complidos estos meses huelguen los dichos yndios quarenta días. ." Cito de acuerdo a la transcripción ofrecida por Ronald D. Hussey, "The Text of the Laws of Burgos Concerning the Treatment of the Indians", The Hispanic American Historical Review, 12 (1932) pp. 301-326. 
